\title{
Language Learning, Ecological Validity, and Innovation under Conditions of Superdiversity
}

\author{
Steven L. Thorne \\ Department of World Languages and Literatures \\ Portland State University, Oregon, USA \\ Department of Applied Linguistics \\ University of Groningen, The Netherlands
}

(Final version received 30 June 2013)

This article describes three pedagogical proposals oriented toward moving language learning to the center of higher education, and further, to emphasizing the importance of both continued first (L1) and additional/foreign (L2) language learning as central to academic and professional success. The first project, titled Language-Integrated Knowledge Education (or LIKE), aims at making explicit the linguistic resources necessary for full participation in written and spoken academic contexts, in both students' first as well as (potentially) multiple foreign languages. The second project describes the benefits and rationale for broadening the use of online intercultural exchange within foreign language education as well as the use of virtual intercultural dialogue in discipline specific (i.e., non-language focused) content courses. The third project, more briefly presented as a concept piece, explores the use of place-based learning through GPS-enabled mobile games in an effort to take language learning resources and activities out of the classroom and into the world. Each of the three proposals is simultaneously modest as well as ambitious. They are modest in that they build from and combine together elements of existing pedagogical approaches to language education, such as telecollaboration, Content and Language Integrated Instruction (CLIL), language focused portfolios, and utilization of mobile technologies to design place-based and augmented reality experiences that are developmentally useful for language learners. They are ambitious because each approach includes an explicit focus on L2 development within traditional language learning contexts (e.g., foreign, world, and modern language departments and courses), but also encourages the broad and systematic integration of language education with other realms of activity, including academic disciplines (the LIKE project), internationally distributed communities (virtual internationalization through online intercultural exchange), and environments/places outside of classrooms (GPS-enabled mobile games). 


\section{Introduction}

This article begins with a brief discussion of two macro-scale conditions that demonstrably impact the processes, and possibly also the desired outcomes, of instructed language education. Condition one: We live in a complex and dynamically changing world in which academic, professional, and everyday life activities increasingly illustrate the need for sophisticated communicative and analytic abilities in intercultural and plurilingual contexts. Building on ideas initially proposed by Vertovec (2007), sociolinguists such as Blommaert and Rampton (2011, p. 2) have described the contemporary era with the term 'superdiversity,' a contested but useful term that seeks to redefine and complexify the ways in which multiculturalism and diversity are conventionally understood. As such, superdiversity "is characterized by mobility and a tremendous increase in the categories of migrants, not only in terms of nationality, ethnicity, language and religion, but also in terms of motives, patterns and itineraries of migration, [and] processes of insertion into ... host societies ..." (Blommaert \& Rampton, 2011, p. 2). As described by Vertovec (2007), superdiversity acknowledges the "coexistence of multiple historical streams and the ways individuals in complex settings relate to each other from different vantage points" (p. 1026). Blommaert and Rampton (2011) suggest a need for a paradigm shift in the study of language in society, one that moves from presumptions of "homogeneity, stability and boundedness" and toward "mobility, mixing, political dynamics and historical embedding" as central to a focus on languages and everyday communicative activity in most contemporary societies (p. 4).

These late modern conditions articulate closely with what I see as one of the primary goals of instructed foreign language and second language (L2) education - to cultivate heightened awareness of dynamic and shifting processes of meaning making and the divergent cultural practices, values, and ideologies that are involved (Thorne, 2011). Such an aspiration for L2 education, however, is difficult to realize without opportunities for dialogic intercultural engagement, experiential language use in the social wilds of everyday life, and careful attention to both discrete language development in a particular linguistic variety (i.e., English, Chinese, Catalan, or Hindi) as well as plurilingual and possibly also polylingual (or mixed language practices, Jørgensen, 2008) 
communicative abilities. This raises a serious question as to the purpose, processes, and goals of instructed language education: In essence, one might ask, what does life-long language development look like under conditions of superdiversity? This question cannot be definitively answered, of course, but a plausible strategy is to develop curricular innovations and pedagogically supported environments that are adaptive to emergent communicative needs, open to a diversity of genres and potentially mixed language communicative dynamics, and that offer experientially and linguistically rich opportunities for engagement.

Condition two: Coupled with the sociolinguistic and communicative entailments of superdiverse urban, virtual, and face-to-face social-interactional engagement, we are now entering a historical period within which publically funded education, and especially non-English foreign language education, is under budgetary threat. This is particularly the case in the United States, United Kingdom, and European Union, where both undergraduate foreign language course offerings as well as language-specific graduate programs of study have been truncated or entirely eliminated. ${ }^{1}$ In the face of increased global interdependence and internationally distributed academic, professional and business activities, this is deeply troubling. One productive response, however, is to leverage superdiversity as a catalyst for reflection and innovation. As a long-term strategy, a primary objective might be to relocate foreign language learning from isolated positions on the periphery of academic content learning and to embed language learning and intercultural engagement throughout educational institutions, and further, into the realms of non-instructed social spaces.

Before continuing to the pedagogical initiatives themselves, let me acknowledge that there are no simple solutions to the creative and adaptive processes that will be necessary to fully revitalize and more centrally locate language education in the $21^{\text {st }}$ century. This said, the following modest-and-ambitious pedagogical proposals attempt to embody ecological validity - the idea that instructed language education might be more adaptively aligned with contemporary conditions of superdiversity and better integrated with the broader intellectual efforts of educational institutions and cultures. 


\section{Proposal 1: The Language-Integrated Knowledge Education (LIKE) approach to plurilingualism and university-level academic discourse competence $^{2}$}

This pedagogical proposal - Language-Integrated Knowledge Education (LIKE) - is designed to make explicit, and thus more readily learnable, the linguistic resources necessary for full participation in written and spoken academic contexts. Academic success requires students to use particular forms of language that include discipline specific vocabulary, collocational patterns, and sensitivity to issues of linguistic register and genre. Indeed, gaining the ability to appropriately and successfully communicate in academic and professional contexts presents challenges for native speakers of the language of instruction as well as for learners of second and foreign languages at all levels. Yet relevant to all academic and professional pursuits is the fact that human knowledge is fundamentally mediated by specialized and technical language, often in tandem with other semiotic systems (e.g., mathematics, computer languages, musical notation, biological and chemical equations, and graphical renderings, among others).

The LIKE approach seeks to improve student success, in university study and beyond, by focusing explicit attention to the discourse practices that are most relevant for subject matter learning, academic writing, and verbal engagement in academic and professional settings. Translated into a pedagogical approach, this involves raising learner awareness of grammatical, lexical, stylistic, and genre choices in order to realize disciplinarily specific meanings for textual, interpersonal, and conceptual purposes. The core of the LIKE approach takes the form of (potentially) plurilingual academic language online portfolios. LIKE portfolios could accompany any course of study - the sciences, mathematics, humanities, social sciences, and professional fields - and would enable university students to actively accumulate, reflect upon, and eventually master relevant academic and/or professional terminology and discourse practices that are central to any branch of knowledge, and to do so in multiple languages. Importantly, using an eportfolio platform would allow students themselves, as well as researchers and related faculty, to empirically track language learning, thus contributing to a better understanding 
of the development of scholarly rhetorical competence in the first and additional languages.

\section{Addressing contemporary challenges}

As described by the literacy and second language acquisition researcher Lilly Wong Fillmore, "What is it that differentiates students who make it from those who do not? This list is long, but very prominent among the factors is mastery of academic language" (2004, n.p.). Put more strongly, mastery of general academic register language as well as discipline specific terminology is catalytic of academic success (e.g., Halliday, 2004; Hyland, 2012). In North America, the issue of academic language development has been prominent in research and educational policies that address the needs of English language learners (e.g., Cummins, 2008; Schleppegrell, 2004). However, considerably less attention has focused on the struggles that many other groups also routinely experience, including native and expert English speakers, many of whom find academic language to be new, difficult, and often obfuscating. Additionally, learners of non-English foreign languages may have limited opportunities to apply the languages they are learning to their major fields of study. Indeed, foreign language learning, especially the first few years of study, is often isolated from other intellectual and knowledge producing dynamics in the academy (i.e., a manifestation of the 'silo problem'). Arraying an emphasis on academic discourse competence across multiple languages has the potential to better integrate foreign languages into the broader intellectual milieu of university life. These are areas in which LIKE could serve large numbers of students during the lengthy process of developing plurilingual discourse abilities that foster trajectories of success in an increasingly mobile and globalizing world.

\section{Theoretical grounding}

The rationale for explicit attention to academic language has a strong research base. Research on student learning outcomes in science, technology, engineering, and mathematics (or STEM) have shown that mastery of discipline specific language fosters academic success (e.g., Sfard, 2008; Halliday, 2004). Sfard, an internationally visible researcher in mathematics education, has gone so far as to describe mathematics relevant 
cognition with the term "commognition", a neologism that combines the words 'communication' and 'cognition.' Sfard's rationale for the notion of commognition is the extensive research that shows the relevance of disciplinary linguistic expertise as a primary factor leading to full participation in academic communities of practice. As described by Sfard, commognition is "grounded in the assumption that thinking is a form of communication and that learning ... is tantamount to modifying and extending one's discourse" (2007, p. 567). Related research suggests that conceptual thinking in fields as diverse as the life sciences, engineering, philosophy, and critical theory are greatly enhanced by mastery of the discourse practices that comprise both written and spoken communication in these fields. Hubbard (2010), for example, has described the use of an exemplary science thesis as the source for developing pedagogical materials for the learning of core academic discourse functions such as defining, contrasting, attribution, hedging, and expressing conditions and findings, among others. More general analyses of spoken and written academic discourse have helped to isolate frequent and recurrent patterns of language use that occur significantly more often in academic than in nonacademic contexts (e.g., Biber, 2006; Conrad \& Biber, 2004; Simpson-Vlach \& Ellis, 2010), the results of which have subsequently been used to develop English for academic purposes instructional resources and which would inform the evolution and implementation of the LIKE approach.

It is also relevant to note the importance of verbal-interactional situations such as classrooms, laboratories, discussion sections, and small group seminars, active participation in which is foundational to conceptual development. As described by Fusaroli \& Tylén:

language is a skillful, joint activity through which interlocutors attune to each other and the task at hand co-constructing a shared cognitive niche. Through social interaction, linguistic practices (words, expressions and whole jargons) are continuously evolved and developed to accommodate local coordinative needs. (2012, p.104)

Full membership in knowledge producing communities (academic and otherwise) requires facility with the historically accumulated discourse, or linguistic exostructure, 
that both enables and constrains context-appropriate forms of communication and coordinated sense-making (Cowley, 2012).

\section{Rationale and existing resources}

As initially conceptualized (but adaptable to local student, faculty, school and/or university interests and goals), a LIKE portfolio would involve a structured but largely independent student-directed process that could be associated with any course or subject matter. It would encourage and help students to design and develop discipline specific language portfolios in English and in other world languages they are studying. For many Bachelor of Arts (B.A.) students, the completion of a foreign language LIKE portfolio could potentially substitute for, or follow, the final term of a mandatory foreign language requirement. This would allow students to apply and expand their developing foreign language abilities to their major field of study, and in some cases, students who would otherwise have been studying a foreign language solely to fulfill a language requirement may become inspired to continue their language learning. International and bi- or plurilingual students could be encouraged to develop LIKE portfolios in both their native language(s) as well as in English. As more students developed LIKE portfolios in multiple languages, a set of discipline specific linguistic repositories would be created that would form the foundation for pedagogically mediated introductions to core linguistic assets that are essential to full participation in the relevant academic discourse communities that comprise a field of study.

The ultimate aim is to embed LIKE portfolios in an open and intelligent adaptive language environment to more fully support the process of student-initiated critical language awareness. Useful features would include access to academic and discipline specific written and spoken language corpora, corpus and computational linguistic tools such as collocations and frequency lists, data driven learning activities (e.g., Johns, 1991; Boulton, 2009), and intelligent computer-assisted language learning (ICALL) tools (Heift, 2010a, 2010b; Heift \& Schulze, 2007; Schulze, 2008). Importantly, students would benefit from orientation to productive use of such tools and thus online tutorials as well as hands-on workshop orientations would be designed (Hubbard \& Romeo, 2012). Lastly, 
building in learning analytics to track user behaviors, in combination with other assessment measures, would provide the data necessary to empirically document diverse usage patterns, their correlations with successful completion of LIKE portfolios, and to support innovation-process research that would iteratively improve the design of the eportfolio environment (Fischer, 2007, 2012).

In terms of practical design and implementation, the LIKE approach benefits from existing pedagogical initiatives such as Content and Language Integrated Learning (or CLIL), which is widely used in the European Union, English for Academic Purposes (EAP), which emphasizes the development of linguistic skills necessary for success in English-speaking academic contexts, and widely used e-portfolio approaches to language study. Exemplars in the latter area include projects emerging as part of the Common European Framework of Reference for Languages, such as the European Language Portfolio $^{3}$, see also Lenz, 2004; Little, 2009), the collaborative oral language proficiency project WebCEF $\left(\mathrm{CEF}=\right.$ Common European Framework $\left.{ }^{4}\right)$, and the foreign language specific LinguaFolio developed at the Center for Applied Second Language Studies ${ }^{5}$, see also Cummins, 2007), among others.

Much like these aforementioned approaches, which presume that students would be developing academic discourse competence in a foreign or second language, the LIKE project was initially conceptualized as a way to encourage English-speaking university students to continue their foreign-language study by applying it to their academic discipline. However, in discussion with numerous university colleagues across various fields, particularly science, technology, engineering and math (or STEM) fields, it became apparent that native speakers of English would also benefit, potentially greatly, from this same approach in their native language. This is especially the case for at-risk populations, such as first generation college students, students who are first or second generation residents of the US (or other English speaking countries), and students from traditionally disenfranchised socioeconomic and ethnic communities. As described by a colleague in the life sciences at a major urban university, success in the study of biology (in English) involves learning a new language, the language of biology (Todd Rosenstiel, personal communication). Development of linguistic and conceptual expertise in one's 
native language (or to borrow again from Sfard (2007) extending ones discipline-specific commognition) also aids conceptual development in additional languages. Cummins, for example, has argued the following:

at deeper levels of conceptual and academic functioning, there is considerable overlap or interdependence across languages. Conceptual knowledge developed in one language helps to make input in the other language comprehensible (2000, p. 39).

This provides the rationale for proposing that all students, across all academic fields, would benefit from explicit attention to the language and genre conventions of their discipline, in both their native language as well as any foreign languages they may be learning or wishing to use for academic purposes in the future.

\section{The process}

LIKE portfolios would begin in the first or native language and early in a student's tenure at university. Questions guiding students could include: What terminology is specific to your field or course of study? What sorts of phrases and collocations (words that probabilistically co-occur with high frequency) do you notice in textbooks, research articles, lectures, and other materials? What vocabulary and patterns of usage seem most relevant for writing lab reports, documenting computer code, presenting business plans, writing proposal abstracts for literature conferences, expressing the clarity of argument encouraged in analytic philosophy, or engaging in post-structural analysis of politics in the public sphere? Exemplars for each of these communicative contexts can be analyzed at the level of morphosyntactic realizations and broader elements of discourse convention, style, and genre, and these are precisely the adaptive linguistic skills that will prepare students for both success in undergraduate education and for academic and professional life post-university. Additionally, examples of communication in online intercultural exchange partnerships (to be discussed below) could be included to provide evidence of the ability to successfully communicate under conditions of linguistic and cultural diversity.

Using an online portfolio shell on a "private" setting, students could keep a running log and accompanying reflective commentary on academic forms of discourse 
that they hear, read, and/or need to incorporate into their written work. Students would be encouraged to initially do this in their native or strongest language, and over time, expand to include foreign languages they are learning. When a LIKE portfolio meets institutionally specific criteria or requirements, it would be submitted for peer review (a system that is now widely and successfully used in MOOCs, and which lessens, but does not completely eliminate, the need for faculty oversight). All LIKE portfolio data would be designed to contribute to the open education movement, potentially resulting in interuniversity and international collaborations and partnerships. Additionally, as part of a LIKE portfolio, students may choose to contribute emerging disciplinary and linguistic expertise to open knowledge fora, such as Wikipedia, that are constantly in need of topical entries in both English and other world languages. In this scenario, LIKE portfolios would benefit participating students as well as contribute to the global knowledge economy.

LIKE portfolios would be repeatable and/or augmentable as students continue to learn more about their major field of study. New languages could be added at any time. The LIKE portfolios themselves could be shared by students with future employers and be used as evidence of academic discourse competence as part of admission to graduate programs. Students who express their ability with world languages through completing LIKE portfolios, and experience the excitement of actually applying a foreign language to their major discipline, may find this experience to be the catalyst that results in continued foreign language study.

\section{Summary}

Students would complete LIKE portfolios in their strongest language and would also have the opportunity to do so in additional languages. Additionally, foreign-language LIKE portfolios would serve to bridge between many universities' one or two-year foreign language requirement and the application of foreign languages to academic and professional topics of relevance. In this way, the LIKE approach addresses a number of pressing contemporary challenges in higher education: (1) Foreign language study at all levels (K-12 and university) is typically separated from most academic fields of study. (2) 
Foreign language departments and programs have suffered due to recent budget constrictions, and part of this stems from the perceived peripheral role of foreignlanguage education vis-à-vis academic and professional success. LIKE would help reposition foreign language learning in the academy as a closely integrated component of discipline specific content learning. (3) In English-medium universities, native speakers of English often experience significant difficulty with both general and discipline specific academic discourse, and thus would benefit from explicit attention to the linguistic resources that enable academic success.

The LIKE approach seeks to heighten students' awareness of academic language through an explicit focus on the discourse expectations that articulate with academic excellence (Blyth, 2009). By having students actively produce LIKE portfolios, and through the process of searching for, selecting, producing, and reflecting on relevant lexical items, phrases, linguistically mediated concepts, and common genre conventions, they will play agentive roles in the construction of the linguistic knowledge relevant to their discipline. As has been long called for in various branches of applied linguistics, LIKE portfolios would also help students as well as external evaluators to empirically and longitudinally track language development (e.g., Fischer, 2007; Ortega \& Byrnes, 2008). Processes that require the explicit objectification of academic discourse have been shown to raise awareness of the importance of using language precisely and purposefully (e.g., McCarthy \& Carter, 1994; Thorne, Reinhardt, \& Golombek, 2008), and thus will cultivate an ability to do so both while immersed in university curricula as well as in professional and intellectual contexts in the future, consequently serving the goal of life long learning.

\section{Proposal Two: Virtual Internationalization through Online Intercultural Exchange}

Addressing contemporary challenges

Contemporary contexts for work, recreation, interpersonal relationships, and economic activity increasingly involve people, ideas, capital, and processes that are distributed around the world. University education, however, often remains bound to classrooms and 
university campuses. This proposal advocates for virtual internationalization, and in particular the use of online intercultural exchange, to bring together internationally dispersed classes, working groups and teams in order to carry out topical and/or projectbased academic activities for mutual benefit. Using widely available internet information and communication tools, the core idea is to enhance opportunities for foreign language learning and also to consider campus-wide pedagogical initiatives to support virtual internationalization partnerships that could potentially become an integral component of any and all subject areas currently taught in higher education institutions.

\section{Rationale and existing resources}

Within foreign language education circles, language learning through intercultural dialogue is one that many educators are now familiar with - the idea that language development is fundamentally rooted in dialogic engagement with other people and that modern communication and information technologies make possible direct engagement with expert speakers of the languages under study. In online intercultural exchange (OIE, also often called 'telecollaboration'), conventional language classroom foci such as grammar, standards of usage, and pragmatics remain important, but conceptual and explicit attention to grammatical form and usage are entwined with, and in some cases arise directly from (e.g., Belz \& Vyatkina, 2008), the communicative dynamics that emerge in the establishment and maintenance of meaningful social relationships that OIE makes possible.

Contemporary OIE pedagogies have a lineage that extends back to the early $20^{\text {th }}$ century educator Célestin Freinet (1994) and OIE continues to be a vibrant theme in current L2 pedagogy and teacher professional development innovation and research (e.g., Dooly \& O'Dowd, 2012; Guth \& Helm, 2010a). Especially since the 1990's, foreign language educators at universities around the world have been organizing online projects to bring their classes into contact with groups of target language speakers with the aim of creating opportunities for authentic communication and first-hand experience of working and learning with collaborators from other language and cultural backgrounds (e.g., MIT's Cultura Project, Furstenberg et al., 2001; telecollaboration projets (e.g., Belz \& 
Thorne, 2006), and tandem learning partnerships (e.g., O'Rourke, 2005); for comprehensive overviews, see O'Dowd, 2007; Thorne, 2006). Research has shown that online exchange projects of this kind can contribute to the development of linguistic accuracy (Kinginger \& Belz, 2005), intercultural awareness (Kramsch, 2011), learner autonomy (Fuchs, Hauck, \& Müller-Hartmann, 2012), intercultural communication abilities (O'Dowd, 2006; Thorne, 2010), and can provide a powerful context for teacher professional development (Belz \& Müller-Hartmann, 2003; Dooly, 2011) that helps to viscerally bring into focus the aforementioned demographics of superdiversity as they relate to diverse classrooms as well as internationally oriented and dialogue-based opportunities for learning.

Given its lengthy history, substantial and supportive research base, and the relative ease of access to and usability of new media, it is surprising that OIE does not play a more central role in instructed L2 contexts. In a recent article, O'Dowd (2011:368) explores reasons for why OIE remains a "peripheral 'add-on' activity in most foreign language classrooms," noting that "normalization" of OIE as an integrated and core pedagogical activity remains a distant reality at most universities and schools. Based on a survey of 73 university-level foreign language instructors working in Europe, all of whom had carried out OIEs, numerous mitigating conditions were expressed, including lack of sufficient pedagogical support and training that would assist with the complexities of OIE planning and execution, the high levels of effort necessary for finding partner classes and aligning curricula, and the variability and not fully controllable nature of OIE (especially in comparison to a closed classroom and syllabus), among others (O'Dowd, 2011).

In an effort to address stated impediments to large-scale adoption of OIE for L2 learning, O'Dowd and colleagues at eight European universities developed a project called INTENT (Integrating Telecollaborative Networks into Foreign Language Higher Education, funded by the European Commission Life Long Learning Programme). Building upon an extensive survey and discussions with higher education teachers, students, and administrators, INTENT has developed a web platform, called UniCollaboration ${ }^{6}$ that makes available numerous resources designed to support both 
experienced and interested newcomers to OIE. Included on the Uni-Collaboration site are a partner search function, a database of individual tasks and task sequences, online training modules, guidelines and rubrics for evaluation, exemplar sample projects that represent a wide range of OIE collaborations, contexts, and foci, and a separate eportfolio tool that has been designed specifically for students involved in OIE projects. The dispersion of innovation benefits from infrastructural support; for language educators interested in OIE, projects such as Uni-Collaboration will greatly facilitate implementation, and potentially the evolution of OIE as a foundational practice, in university level foreign language education.

\section{Extending OIE and language education across contexts and disciplines}

As discussed above, while OIE has a substantial history within foreign language learning communities, there exists a parallel movement to scale up opportunities for virtual exchange for purposes of transcultural understanding and to heighten awareness of social justice issues. Examples include the Soliya Connect Program, which focuses primarily on virtual exchanges and online moderated dialogue in order to bring together young people from the 'West' and Muslim/Arab world. As stated on the website ${ }^{7}$ approximately 2,600 students from more than 100 universities have participated across 27 countries in the Middle East, North Africa, South Asia, Europe and North America since 2003. The primary purpose of these exchanges is to "to shift the way societies resolve their differences from a confrontation and coercive approach to one defined by cooperation and understanding" (cited from same website) ${ }^{8}$. The potential for engagement in multiple languages is an obvious possibility through Soliya's broad network and in a recent study, Helm, Guth, and Farrah (2012) investigated such an exchange between English language students in Hebron, Palestine and Padova, Italy. Topics included religion (especially Islam), history, and politics, often in relation to the students' life experiences. A noteworthy feature of this study is that issues of cultural, linguistic, and technological hegemony are explicitly foregrounded in the analysis, an issue that has been raised as an important but under-explored aspect of OIE in prior research (e.g., Ess, 2009; Guth \& Helm, 2010b; Lamy \& Goodfellow, 2009; Thorne, 2003). As a caveat, the authors note 
that the study is largely descriptive and language learning per se is not addressed. However, this research suggests a number of significant pedagogical affordances with direct relevance for expanding OIE to language-rich (the use of EFL, in this case), but non-foreign language focused instruction. Findings included the value of positioning EFL learners as part of an international dialogue group rather than as language learners, the potential for an emergent "third space" (e.g., Bhabha, 1994; Kramsch, 1993) that allowed the students to develop trust and empathy in the context of controversial topics, and the benefit of trained facilitators who could help transform conflict into learning opportunities. As of 2011, Soliya has entered a partnership with iEARN and Global Nomads Group to form the Exchange 2.0 Coalition, a collective entity that serves primary and secondary students as well as those at higher education levels.

For younger students, and for university students in a variety of disciplines (history, international affairs, political science, sociology, peace studies, etc.), the Exchange 2.0 Coalition offers the opportunity to grapple with difference through dialogue and direct experience. This suggests the possibility for a re-orientation of educational practice to emphasize the development of intercultural understanding and communicative competence as central to what 'internationalization' actually means in terms of student learning outcomes. It is not an over-bold statement to suggest that the pedagogical interest in online intercultural exchange approaches are catalyzing a new synergy within university education, one in which linguistic accuracy and discourse competence continue to play roles, but in the service of cultivating the ability to achieve interactionally emergent understanding in a superdiverse and interdependent world. As with the LIKE approach described above, virtual internationalization through online intercultural exchange has the potential to distribute foreign language learning across curricular and disciplinary lines, and hence to create project and content based opportunities for academic engagement that might include languages of wider communication as well as languages that are less commonly taught or which are the principle academic focus of the course in question. Actual engagement in intercultural communication also brings to the fore the relevance of code-switching and polylingual languaging (the latter defined as situations in which speakers relevantly combine features 
of multiple languages to achieve and maintain communication, e.g., Jørgensen, 2008; see also Jørgensen, Rindler-Schjerve, \& Vetter, 2012).

\section{Summary}

To summarize, the rationale for the systemic implementation of virtual internationalization through OIE is multifold: First, it is clear that contemporary research networks, professional activity, and commercial viability are already demonstrably international in scope. Therefore, including opportunities for international engagement as part of university level course work increases the ecological validity of students' campus based learning as it relates to post-university life, and thus better prepares them for full participation in future work and professional contexts. Second, many universities have a stated long-standing commitment to internationalization, thus including virtual international experience as part of routine coursework would serve to increase student (and faculty) opportunities for intercultural exchange and the transnational sharing of ideas. Third, for students who may have practical or financial constraints that might otherwise preclude international travel or study, virtual internationalization would provide them with direct exposure to other cultures, perspectives, values, ideas, and where relevant, engagement with speakers of languages they wish to learn, that might otherwise not be available.

Research has demonstrated that participants in OIE activities undergo substantial shifts in cultural openness (Bruneau \& Saxe, 2012), become more adept at intercultural communication with international collaborators (O'Dowd, 2006), gain experience with diverse and globally distributed worldviews (Helm et al., 2012), and build academic and interpersonal relationships of significance that can extend beyond the immediacy of the OIE activities themselves. A final point is that by expanding OIE to include, for example, academic fields such as STEM (Science, Technology, Engineering and Mathematics), social science and non-language humanities subjects, budding scholars would gain exposure to international contexts and perspectives, with the potential side effect of becoming interested in world languages and cultures. 


\section{Proposal three: Mobile Augmented Reality Games for Learning}

\section{Addressing contemporary challenges}

In the new millennium, emerging mobile and digital technologies have had a profound effect on information and communication practices - from interpersonal communication and social coordination to the on-demand and just-in-time dynamics that shape everyday uses of information. While mobile technologies saturate everyday life, they are only recently coming to support, and in some cases to transform, learning opportunities and processes. This brief project description proposes the use of mobile media and placebased augmented reality techniques to create multilingual learning opportunities for language students. Augmented Reality (hence forth AR) or place-based language learning activities, such as participation in game-based narratives, tours, and in-the-world quests, involve physical movement through local and/or regional environments. Under the umbrella framework of mobile locative learning, this approach leverages the power and increasing ubiquity of mobile and GPS enabled devices to engage participants in language-rich experience outside of the classroom.

\section{Description and rationale}

The more exciting developments in contemporary digital learning have recently come to include 'serious' games. The concept of ludic engagement as a form of developmentally productive activity has likely existed for as long as have formal approaches to teaching and learning. A compelling illustration from the serious games movement is the work of Jane McGonigal (2011), who harnesses the motivational elements of game mechanics in order to create experiences intended to raise awareness of, and critical thinking about, humanitarian, ecological, and societal issues. In similar work, Ian Bogost $(2007,2011)$ has described the use of digital games for documenting historical and cultural events as spaces for artistic and political engagement. In scientific research communities, games like Phylo suggest that when good game mechanics are coupled with actual DNA research data, human gamer-analysts can contribute to solving difficult problems such as multiple sequence alignment and biomolecule design (as reported in Nature, March 12, 2012 and January 22, 2012 respectively ${ }^{9}$ ). 
The particular focus here, AR games, attempt to create scenarios and prompts that encourage participants to expand beyond the traditional subject positions associated with that of 'student' or 'learner' (a quality shared with some approaches to OIE, described above). AR games are a more recent entry into the arena of educationally oriented game development, but similar to commercial recreational games that have been studied as learning environments (e.g., Gee, 2007; Thorne, 2012; Thorne, Black, \& Sykes, 2009; Sykes \& Reinhardt, 2013), AR games represent a shift away from models of learning based on information delivery and toward theories of human development rooted in experiential and situated problem solving. AR games are rapidly appearing in museums, community-based education projects, and more slowly, in formal educational settings. Existing AR games (e.g., Holden \& Sykes, 2011) and accompanying mobile resources for learning share certain objectives: 1) to increase engagement in the language learning process by moving students and language learning experiences out of the classroom and into the world; 2) to provide in situ prompts and activities that align with existing language learning curricular objectives; and 3) to offer ubiquitous access to mobile language learning resources and activities.

\section{The process}

AR games involve movement through environments (cities, landscapes) using GPSenabled devices as a guide. As Squire (2009:70) describes:

Although mobile media learning has mostly been framed as " anytime, anywhere", their more profound impact may be in the experience of place. Mobile media enables a multiplicity and hybridity of place that causes opportunities and challenges to learning and education.

Designing AR games to highlight and more fully understand and appreciate specific places is a growing phenomenon, with numerous projects that include scientific themes (e.g., metallurgy), urban studies, architecture, and history ${ }^{10}$. Two brief foreign language AR games will help to describe the potential of this technology. The first, created by Holden and Sykes (2011), is designed for university-level intermediate Spanish learners. The game, called Mentira ('lie', 'deception'), takes place in Los Griego, a traditionally Spanish-speaking neighborhood in Albuquerque, New Mexico, in the Southwest of the 
United States. The game takes students to six locations, each of which has historical significance and contributes to solving a murder mystery that comprises the central theme of the game. Local residents are enthusiastic to engage with students and the game serves to connect the university to the community. Students take on roles as a member of one of four possible families that are implicated in the murder. They investigate, share clues, and attempt to clear their family's name. In a recent iteration of Mentira, the summative event is an in-class criminal trial. Along the way, students produce multiple homework assignments that involve writing and preparation for presentations. Notably, for many of the students, the majority of whom were white, playing Mentira brought them to this historically ethnic Spanish neighborhood for the first time.

A second example of a multilingual AR game recently developed at Portland State University (PSU) by an on campus group (the "503 Design Collective," a team of undergraduate students and faculty), which takes PSU's emphasis on green technology and sustainability as its core focus, is called ChronoOps. In this AR game, students play the role of an agent from the future (the year 2070). The game narrative is that in the year 2070, the planet has suffered massive environmental degradation and the player-agent has been sent back in time to the year 2013 in order to learn from the "simultaneous dawn and dusk of green technology" that is in evidence on and around the PSU campus (located in Portland, Oregon). When players enter certain physical locations, they receive video, audio, or text information and/or directions in one of three possible languages (English (for ESL students), French, or Spanish). Players are given tasks that result in visits to the electric avenue (a location where electric cars can be recharged), a large solar array producing electricity for the city, local public community gardens, recycling projects, and environmentally designed "green structures" on campus. En route, players are prompted, in their role as agents tasked with investigating sustainability projects that could yet save the future of the planet, to record verbal narratives of what they observe using the target language. At various points, they are also asked to make text notes, shoot video, and take photographs, all of which are later used in foreign language assignments such as the production of written reports and oral presentations. Participants are asked to play in small teams (2-4 people) and group interaction while playing the game involves 
various types of task-related and socially oriented communication. The text, audio, video, and images produced by players subsequently contribute new game content for future players and provide archived data for later analysis and use in classroom settings.

Drawing on the multilingual international population at most universities, a particularly innovative feature to AR games is their relative simplicity to create. This allows for players to contribute game content, and with training, to actually design and make AR games as a language learning activity. An innovative approach that the Portland State design team is working toward is to have international as well as American foreign language students play the game, at different times, in both their native/expert language as well as the language they wish to learn. Native/expert language data can be used as content for learners of that language (as exemplars of prompted narratives and tasks, for example), while language learner data can be archived for second language acquisition research, for use in classrooms by instructors, and to provide feedback and error correction. Additionally, international students (speakers of language other than English in this case) produce value through sharing their native language expertise gives them a significant epistemic role in the production of knowledge on campus. Reciprocally, native and/or expert English speakers can contribute to the repository of mobile resources that would benefit international students and ESL learners. Other beneficiaries include non-language students and the general public, since all plurilingual AR games, guides, tours and activities are being designed in compliance with the Open Education movement (Blyth, 2013).

\section{Summary}

Human languages and communicative activity are distributed across social and material landscapes, only one of which is the space of the traditional classroom. Mobile technologies allow for many of the semiotic resources and activities that are typically used in the classroom to be available outside of formal instructional settings. Additionally, uses of mobile AR technology as part of scenario-, project-, or narrative game-based activities unite embodied engagement with academic and linguistic tasks outside of the classroom. Mobile learning is a recently developed and rapidly growing resource in 
higher education. As a new arrival to technology-mediated foreign language education, there are many processes and dynamics yet to work out, but existing experiments appear promising.

\section{By way of conclusion}

This article began by describing two significant and large-scale developments. The first is evidence for what has been described as superdiversity in contemporary societies - that human populations are increasingly mobile, and with this comes a suitable rupture of the myth of homogeneous linguistic varieties that are stable and predictable. This is not to say that foreign language educators should neglect attention to historically stable genres of language (especially formal written genres of communication and preparation for high stakes and standardized language assessments); in fact, the LIKE project emphasizes the mastery of stable academic discourse genres in both the L1 as well as additional languages. Rather, the notion of superdiversity and its relation to rapidly changing patterns of communication suggests that for some purposes and contexts, the very target that informs the goal of communicative competence is likely shifting, and perhaps shifting more rapidly than has been the case in the past. This is certainly visible in the proliferation of online speech communities, where usage and forms of written expression have emerged quickly and with significant variance from conventional written and spoken genres of communication. As descriptive linguists have long argued, what is typically referred to as grammar is more usefully understood as observable, recurrent, and yet malleable patterns of expressive activity (Hopper, 1998; see also Otsuji \& Pennycook).

Orienting foreign language education toward a moving target presents obvious challenges, but it also brings living language into view in a way that can ecologically align the efficacy of classroom instruction with real world communicative needs. The three projects address this dynamic in different ways: the LIKE approach is primarily attuned to inductively noticing, and subsequently developing, an inventory of academic genre language in order to be able to fully participate in knowledge producing university communities. Online intercultural exchanges position language learners as dialogic 
partners, with corresponding exposure to diverse people, communicative styles, and linguistic varieties, in addition to engagement with a plurality of perspectives and worldviews. Mobile AR games help to emplace language into the world and to create a sense-saturated communicative experience that subsequently can be revisited and elaborated with the guidance of an instructor or through collaboration with peers. In each case, the pedagogy emphasizes agency, and ultimately self-regulation, on the part of participants.

The second large-scale issue involves decreasing institutional resources for nonEnglish foreign language education. Here, I have attempted to argue that increasing the centrality of languages in university institutional cultures is both a worthy (for students) and a necessary (for the foreign language field and community) move. Foreign language education is becoming increasingly separated from the broader intellectual fabric of the academy and at a time when plurilingualism would seem to be most salient to project of empathetically engaging with and understanding the heterogeneity, and often the fluidity, of others' as well as one's own culturally informed dispositions and beliefs.

Let me conclude with a recent popular press assessment of higher education's overarching mission that is broadly congruent with the projects ideas presented above. On January $5^{\text {th }}$, 2013, the New York Times op-ed columnist Frank Bruni published an editorial that was titled "How to Choose a College." In this piece, his first words of advice were to choose a university that offered opportunities for developing an internationally aware and agile disposition, stating that:

globalism is here and real. The dexterity with which you can navigate other cultures - your awareness of, and openness to, them - could be more valuable ... than any knowledge gleaned from a book. The world is in constant flux, life is a sequence of surprises, and I can think of no better talents to pick up in college than fearlessness, nimbleness and the ability to roll with change, adapt to newness and improvise.

With collective, inspired, dialogic, adaptive, and continued reinvention, foreign language education has the potential to serve precisely these goals. 


\section{Bibliographical References}

Belz, J. A., \& Müller-Hartmann, A. (2003). Teachers as intercultural learners: Negotiating German-American Telecollaboration along the institutional fault line. Modern Language Journal, 87(1), 71-89.

Belz, J., \& Thorne, S. (Eds.) (2006). Internet-mediated intercultural foreign language education. Boston, MA: Thomson Heinle.

Belz, J., \& Vyatkina, N. (2008). The pedagogical mediation of a developmental learner corpus for classroom-based language instruction. Language Learning \& Technology, 12(3), 33-52.

Bhabha, H. (1994). The location of culture. New York: Routledge.

Biber, D. (2006). University language: A corpus-based study of spoken and written registers. Amsterdam: John Benjamins.

Blommaert, J., \& Rampton, B. (2011). Language and superdiversity: A position paper. Working Papers in Urban Language \& Literacies Paper 63, 2-22. Available at: http://www.kcl.ac.uk/innovation/groups/ldc/publications/workingpapers/70.pdf

Bogost, I. (2007). Persuasive games: The expressive power of video games. Cambridge, Mass.: MIT Press.

Bogost, I. (2011). How to do things with video games. Minneapolis: University of Minnesota Press.

Bruneau, E., \& Saxe, R. (2012). The power of being heard: The benefits of 'perspectivegiving' in the context of intergroup conflict. Journal of Experimental Social Psychology, 48, 855-866.

Blyth, C. (2009). The impact of pedagogical materials on critical language awareness: Assessing student attention to patterns of language use. In Turnbull, M., \& J. Dailey-O'Cain (Eds.). First language use in second and foreign language learning (pp. 156-178). London: Multilingual Matters.

Blyth, C. (2013). LCTLs and technology: The promise of open education. Language Learning \& Technology, 17(1), 1-6.

Boulton, A. (2009). Testing the limits of data-driven learning: Language proficiency and training. ReCALL Journal, 21(1), 37-54.

Conrad, S., \& Biber, D. (2004). The frequency and use of lexical bundles in conversation and academic prose. Lexicographica: International Annual for Lexicography, 20, 56-71.

Cowley, S. (2012). Linguistic fire and human cognitive powers. Pragmatics \& Cognition, 20(2), 275-294.

Cummins, J. (2000). Language, power, and pedagogy: Bilingual children in the crossfire. Clevedon, England: Multilingual Matters.

Cummins, P. (2007). LinguaFolio and electronic portfolios in teacher training. In M. Kassen, R. Lavine, K. Murphy-Judy, \& M. Peters (Eds.), Preparing and developing technology-proficient L2 teachers (pp. 321-344). San Marcos, TX: CALICO.

Cummins, J. (2008). BICS and CALP: Empirical and theoretical status of the distinction. In B. Street \& N. H. Hornberger (Eds.), Encyclopedia of Language and Education, 
2nd Edition, Volume 2: Literacy. (pp. 71-83). New York: Springer Science + Business Media LLC.

Dooly, M. (2011). Crossing the intercultural borders into 3rd space culture(s): implications for teacher education in the twenty-first century. Language and Intercultural Communication, 11 (4), 319-337.

Dooly, M., \& O'Dowd, R. (Eds.) (2012) Researching online interaction and exchange in foreign language education. Theories, methods and challenges. Bern: Peter Lang.

Ess, C. (2009). When the solution becomes the problem: Cultures and individuals as obstacles to online learning. In R. Goodfellow \& M-N. Lamy (Eds.), Learning cultures in online education (pp. 5-29). London: Continuum.

Fillmore, L. W. (2004). The role of language in academic development. Keynote address, presented at "Closing the Achievement Gap for EL Students," a conference convened by the Sonoma County Office of Education, April 2004.

Fischer, R. (2007). How do we know what students are actually doing? Monitoring students' behavior in CALL. Computer Assisted Language Learning, 20(5), 409442.

Fischer, R. A. (2012). Diversity in learner usage patterns. In G. Stockwell (Ed.), Computer-assisted language learning diversity in research and practice (pp. 1432). Cambridge: Cambridge University Press.

Freinet, C. (1994). Oeuvres pédagogiques. Paris: Editions du Seuil.

Fuchs, C., Hauck, M., \& Müller-Hartmann, A. (2012). Promoting learning autonomy through multiliteracy skills development in cross-institutional exchanges. Language Learning \& Technology, 16(3), 82-102.

Furstenberg, G., Levet, S., English, K., and Maillet, K. (2001). Giving a virtual voice to the silent language of culture: The CULTURA project. Language Learning \& Technology, 5(1), 55-102.

Fusaroli, R., \& Tylén, K. (2012). Carving language for social coordination: A dynamical approach. Interaction Studies, 13(1), 103-124.

Gee, J. (2007). Good video games and good learning. New York: Peter Lang.

Guth, S., \& Helm, F. (Eds). (2010a). Telecollaboration 2.0: Language, literacies and intercultural learning in the 21 st Century. Bern: Peter Lang.

Guth, S., \& Helm, F. (2010b). Introduction. In S. Guth \& F. Helm (Eds.), Telecollaboration 2.0: Language, literacies and intercultural learning in the 21st Century (pp. 13-35). Bern: Peter Lang.

Halliday, M. A. K. (2004). The language of science. Continuum: London.

Heift, T. (2010a). Prompting in CALL: A longitudinal study of learner uptake. Modern Language Journal, 94(2), 198-216.

Heift, T. (2010b). Developing an Intelligent Language Tutor. CALICO Journal, 27(3), 443-459.

Heift, T. \& Schulze, M. (2007). Errors and intelligence in computer-assisted language learning: Parsers and Pedagogues. New York: Routledge.

Helm, F., Guth, S., \& Farrah, M. (2012). Promoting dialogue or hegemonic practice?

Power issues in telecollaboration. Language Learning \& Technology, 16(2), 103127.

Holden, C., \& Sykes, J. (2012). Leveraging mobile games for place-based language 
learning. International Journal of Game-Based Learning, 1(2), 1-18.

Hopper, P. (1998). Emergent grammar. In M. Tomasello (Ed.), The new psychology of language: Cognitive and functional approaches to language study (pp. 155-175). Mahwah, NJ: Erlbaum.

Hubbard, P. (2010). Reflections on teaching discourse functions using a science thesis. Journal of Writing and Pedagogy: 1(2), 264-277.

Hubbard, P., \& Romeo, K. (2012). Diversity in CALL learner training. In G. Stockwell \& M. Thomas (Eds). Computer-Assisted Language Learning: Diversity in Research and Practice (pp. 33-48). Cambridge: Cambridge University Press.

Hyland, K. (2012). Bundles in academic discourse. Annual Review of Applied Linguistics, 32, 150-169.

Johns, T. (1991). Should you be persuaded - two examples of data-driven learning materials. In T. Johns \& P. King (Eds.), Classroom concordancing. English Language Research Journal (Vol. 4, pp. 1-16): Birmingham University.

Jørgensen, J. N., Rindler-Schjerve, R., \& Vetter, E. (2012). Polylingualism, multilingualism, plurilingualism. A toolkit for transnational communication in Europe. Copenhagen Studies in Bilingualism. Available at: http://www.toolkitonline.eu/docs/polylingualism.html

Jørgensen, J. N. (2008). Polylingual languaging around and among children and adolescents. International Journal of Multilingualism, 5(3), 161-176.

Kinginger, C., \& Belz, J. A. (2005). Sociocultural perspectives on pragmatic development in foreign language learning: Microgenetic case studies from telecollaboration and residence abroad. Intercultural Pragmatics, 2(4), 369-422.

Kramsch, C. (1993). Context and culture in language teaching. Oxford: Oxford University Press.

Kramsch, C. (2011). The symbolic dimensions of the intercultural. Language Teaching, 44(3), 354-367.

Lenz, P. (2004). The European Language Portfolio. In K. Morrow (Ed.), Insights from the Common European Framework (pp. 22-31). Oxford: Oxford University Press.

Little, D. (2009). The European Language Portfolio: Where pedagogy and assessment meet. Strasbourg: Council of Europe.

McCarthy, M., \& Carter, R. (1994). Language as discourse: Perspectives for language teaching. London: Longman.

McGonigal, J. (2011) Reality is broken: Why games make us better and how they can change the world. New York: The Penguin Press.

O'Dowd, R. (2006). Telecollaboration and the development of intercultural communicative competence. Berlin: Langenscheidt.

O’Dowd, R. (Ed.) (2007). Online intercultural exchange: An introduction for foreign language teachers. Clevedon: Multilingual Matters.

O'Dowd, R. (2011). Online foreign language interaction: Moving from the periphery to the core of foreign language education? Language Teaching, 44(3), 368-380.

O'Rourke, B. (2005). Form-focused interaction in online tandem learning. CALICO Journal 22.3, 433-466.

Ortega, L., \& Byrnes, H. (Eds.). (2008). The longitudinal study of advanced L2 capacities. New York: Routledge. 
Otsuji, E., \& Pennycook, A. (2010). Metrolingualism: Fixity, fluidity and language in flux. International Journal of Multilingualism, 7(3), 240-254.

Schleppegrell, M. (2004). The language of schooling: A functional linguistics perspective. Mahwah, NJ: Erlbaum.

Schulze, M. (2008). AI in CALL: Artificially inflated or almost imminent? CALICO Journal, 25 (3), 510-527.

Sfard, A. (2007). When the rules of discourse change, but nobody tells you: Making sense of mathematics learning from a commognitive standpoint. Journal of the Learning Sciences, 16(4), 567-615.

Sfard, A. (2008). Thinking as communicating: Human development, the growth of discourses, and mathematizing. Cambridge, UK: Cambridge University Press.

Simpson-Vlach, R., \& Ellis, N. C. (2010). An Academic Formulas List (AFL). Applied Linguistics, 31, 487-512.

Squire, K. D. (2009). Mobile media learning: Multiplicities of place. Horizon, 17(1), 7080.

Sykes, J., \& Reinhardt, J. (2013). Language at play: Digital games in second and foreign language teaching and learning. New York: Pearson.

Thorne, S. L. (2003). Artifacts and cultures-of-use in intercultural communication. Language Learning \& Technology, 7(2), 38-67.

Thorne, S. L. (2006). Pedagogical and praxiological lessons from Internet-mediated intercultural foreign language education research. In J. Belz \& S. L. Thorne (Eds.), Internet-mediated intercultural foreign language education (pp. 2-30). Boston: Thomson Heinle Publishers.

Thorne, S. L. (2010). The "intercultural turn" and language learning in the crucible of new media. In F. Helm \& S. Guth (Eds.), Telecollaboration 2.0 for language and intercultural learning (pp. 139-164). Bern, Switzerland: Peter Lang.

Thorne, S. L. (2011). Community formation and the world as its own model. Modern Language Journal, 95, 304-307.

Thorne, S. L. (2012). Gaming writing: Supervernaculars, stylization, and semiotic remediation. In G. Kessler, A. Oskoz, \& I. Elola, (eds.), Technology across writing contexts and tasks (pp. 297-316). CALICO Monograph: San Marcos, Texas.

Thorne, S. L. (2013). Catalyzing Plurilingualism and University-level Academic Discourse Competence: The Language-Integrated Knowledge Education (LIKE) Approach. In P. Hubbard, M. Schulz, \& B. Smith (eds.), Learner-Computer Interaction in Language Education: A Festschrift in Honor of Robert Fischer (pp. 263-271). CALICO Monograph: San Marcos, Texas.

Thorne, S. L., Black, R. W., \& Sykes, J. (2009). Second language use, socialization, and learning in Internet interest communities and online gaming. Modern Language Journal, 93, 802-821.

Thorne, S. L., Reinhardt, J., \& Golombek, P. (2008). Mediation as objectification in the development of professional discourse: A corpus-informed curricular innovation. In J. P. Lantolf \& M. Poehner (Eds.), Sociocultural theory and the teaching of second languages (pp. 256-284). London: Equinox.

Vertovec, S. (2007). Super-diversity and its implications. Ethnic and Racial Studies 30/6, 


\section{4-1054.}

\section{Author References}

Steven L. Thorne holds faculty appointments in the Department of World Languages and Literatures at Portland State University (USA) and the Department of Applied Linguistics at the University of Groningen (The Netherlands). His research interests include interpenetrations between historically differentiated systems of activity, the cultures-of-use of Internet communication tools, multiplayer online gaming, intercultural communication, indigenous language education, and work that draws upon cultural-historical activity theory, contextual traditions of language analysis, and usage-based and distributed approaches to language development.

\section{Email: steven.thorne@pdx.edu}

To cite this article:

Thorne, S.L. (2013). Language Learning, Ecological Validity, and Innovation under Conditions of Superdiversity. Bellaterra Journal of Teaching \& Learning Language \& Literature, 6(2), 1-27.

\footnotetext{
${ }^{1}$ An internet search for the string 'foreign languages and budget cuts' will bring up hundreds of relevant articles that report reduced funding or the complete dismantling of secondary school and university foreign language courses, programs, and degrees.

${ }^{2}$ An earlier version of the LIKE project concept was initially published in Thorne 2013. This section draws extensively from that publication.

${ }^{3}$ http://www.coe.int/t/dg4/education/elp/

${ }^{4} \mathrm{http} / / / \mathrm{www}$. webcef.eu/

${ }_{6}^{5} \mathrm{https} / / /$ linguafolio.uoregon.edu

${ }^{6} \mathrm{http} / / /$ unicollaboration.eu/

${ }^{7}$ http://www.soliya.net/

8 http://www.soliya.net/

9 "Gamers outdo computers at matching up disease genes: Computer game crowdsources DNA sequence alignment across different species." Nature, doi:10.1038/nature.2012.10203; 2) "Victory for crowdsourced biomolecule design: Players of the online game Foldit guide researchers to a better enzyme." Nature, doi:10.1038/nature.2012.9872

${ }^{10}$ For examples, see http://arisgames.org/
} 